\title{
Chemical composition, antioxidant and antibacterial activities of the essential oils of Juniperus phoenicea, Juniperus thurifera and Juniperus oxycedrus
}

\author{
Rachid Rahhal ${ }^{1}$, Houda EL Hajjouji ${ }^{1,2, *}$, Said Gmouh ${ }^{3}$, Mohammed Hsaine ${ }^{1}$, Hassan Fougrach ${ }^{1}$ and \\ Wadi Badri ${ }^{1}$ \\ ${ }^{1}$ University Hassan II of Casablanca, Faculty of Sciences Ben M'Sik, Laboratory of Ecology and Environment, \\ Casablanca, Morocco \\ ${ }^{2}$ Higher Institute of Nurses Professions and Health Techniques, Béni-Mellal, Morocco \\ ${ }^{3}$ University Hassan II of Casablanca, Faculty of Sciences Ben M'Sik, Laboratory of Engineering and Materials, \\ Casablanca, Morocco
}

\begin{abstract}
This study aimed to compare the chemical composition, the antioxidant activity and the antibacterial activity of essential oils (EOs) of Juniperus phoenicea, Juniperus thurifera and Juniperus oxycedrus, obtained from Ait Bouguemez region (Province of Azilal, Morocco). The analysis by GC/MS of essential oils led to identify 37, 54 and 38 components for J. phoenicea, J. thurifera, and J. oxycedrus, respectively. Monoterpenic fraction was found predominant in essential oils of the three samples. The DPPH free radical scavenging activity showed that essential oil of $J$. thurifera has the strongest antioxidant activity with an IC50 value of $12.07 \mu \mathrm{g} / \mathrm{mL}$. The antibacterial activity showed that $S$. aureus was more sensitive than $P$. aeruginosa and E. coli for the three EOs tested.
\end{abstract}

Keywords: Juniperus; Essential Oils; GC/MS; Antioxidant activity; Antibacterial activity.

\section{Introduction}

Juniperus species (genus Juniperus, family of Cupressaceae) belong to the coniferous plants is an important component of arid and semi-arid ecosystems throughout the northern hemisphere ${ }^{1,2}$. This genus is the second most diverse genus of the conifers, it is consisting of approximately 67 species and 28 varieties ${ }^{1}$.

In Morocco, the genus Juniperus is present in several places among which the valley of Ait Bouguemez (Province of Azilal, Morocco) where we find the three species J. phoenicea, J. thurifera and J. oxycedrus. The valley of Ait Bouguemez is located in the central High Atlas limestone (Morocco). It extends at an altitude ranging from 1800 to 2200 m over nearly 30 $\mathrm{km}^{3}$.

Juniperus is one of the most used genus by the traditional healers in central High Atlas of Morocco ${ }^{4-7}$. Juniperus tar, leaves and fruits are employed to heal wounds, abdominal pain and stomachic disorders, metabolic diseases, and against fungal infections ${ }^{4-6}$. The treatment of infections and health disorders with herbal medicines is usually involves active natural products mostly of low

*Corresponding author: Houda EL Hajjouji

Email address: elhajjouji.ispits@gmail.com

DOI: http://dx.doi.org/10.13171/mjc93191002145heh molecular weight of great structural diversity. These substances traditionally referred to as secondary metabolites, often are differentially distributed among limited taxonomic groups within the plant kingdom ${ }^{8,9}$. The function or importance of secondary metabolites in plants is ecological. It is for interactions between the plants and their environment ${ }^{10,11}$. Secondary metabolites include three major classes: terpenoids, alkaloids and phenolics. They contain numerous natural products, some of which have good pharmacological properties especially essential oils (EOs) ${ }^{12,13}$.

Many studies around the world have been performed on the chemical composition of the EOs and extracts of Juniperus species. Juniperus Oils and extracts contain various chemotypical compounds: from 2,6dimethyloctane to sesquiterpene skeletons, and flavonoids and biflavonoids, but the main classes identified in almost all Juniperus are mono and sesquiterpenoids and their derivatives ${ }^{14-18}$.

Many constituents present in Juniperus EOs are responsible for their biological properties ${ }^{8}$. According to Majewska ${ }^{19}$, EOs of Juniperus species showed antimicrobial activity against Gram-positive 
bacteria: Bacillus cereus ATCC 11778, Bacillus subtilis NCTC 8236, Micrococcus flavus MFBF, Micrococcus luteus ATCC 9341, Staphylococcus aureus ATCC 6538, Staphylococcus aureus MFBF, Staphylococcus epidermidis MFBF and Enterococcus faecalis MFBF. Gram-negative bacteria were also sensitive to Juniperus EOs. Misharina ${ }^{20}$ reported that EOs of Juniperus species have a strong antioxidant activity and it depends on the nature and concentration of EOs components and also the geographical origin of plant.

In this regard, the purpose of this research is both to explore the chemical composition of EOs of the Juniperus species growing in valley of Ait Bouguemez in comparison to the EOs from other Mediterranean countries and to evaluate the antioxidant and antibacterial activities of the EOs tested.

Table 1. Characteristics of sites of sampling.

\begin{tabular}{|c|c|c|c|c|}
\hline & Altitude $(\mathbf{m})$ & Latitude-longitude & Soil & Bioclimatic stage \\
\hline J. phoenicea & 1870 & $31^{\circ} 63^{\prime} \mathrm{N}-6^{\circ} 44^{\prime} \mathrm{W}$ & Limestone & Semi-arid \\
\hline J. thurifera & 2200 & $31^{\circ} 65^{\prime} \mathrm{N}-6^{\circ} 41^{\prime} \mathrm{W}$ & Limestone & Semi-arid \\
\hline J. oxycedrus & 1950 & $31^{\circ} 62^{\prime} \mathrm{N}-6^{\circ} 46^{\prime} \mathrm{W}$ & Limestone & Semi-arid \\
\hline
\end{tabular}

\subsection{Extraction of the EO}

Dry aerial parts $(100 \mathrm{~g})$ of the three species were subjected to the hydrodistillation for three hours, using a cleavenger-type apparatus, according to the Pharmacopoeia to produce Eos ${ }^{21}$. The obtained EOs were stored at $+4{ }^{\circ} \mathrm{C}$ until use.

\subsection{GC/MS analysis}

The EOs were analyzed on a Hewlett-Packard gas chromatograph Model 5890, coupled to a HewlettPackard model 5971, equipped with a DB5 MS column (30 m X $0.25 \mathrm{~mm} ; 0.25 \mu \mathrm{m})$, programming from $50^{\circ} \mathrm{C}(5 \mathrm{~min})$ to $300^{\circ} \mathrm{C}$ at $5^{\circ} \mathrm{C} / \mathrm{min}$, with a $5 \mathrm{~min}$ hold. Helium was used as the carrier gas $(1.0 \mathrm{~mL} / \mathrm{min})$; injection in split mode (1:30); injector and detector temperatures, 250 and $280^{\circ} \mathrm{C}$, mode at $70 \mathrm{eV}$; electron multiplier, $2500 \mathrm{~V}$; ion source temperature, $180^{\circ} \mathrm{C}$; MS data were acquired in the scan mode in the $\mathrm{m} / \mathrm{z}$ range $33-450$. The identification of the components was based on comparison of their mass spectra with those of NIST mass spectral library (NIST 2011) as well as on comparison of their retention indices either with those of authentic compounds or with literature values ${ }^{1}$.

\subsection{Antioxidant activity}

The slightly modified method of Pothitirat et al. ${ }^{22}$ was of great help to assess the radical scavenging abilities of EOs. $0.5 \mathrm{~mL}$ of various concentrations of $\mathrm{EO}$ and standards butylhydroxytoluene (BHT), vitamin C and $\alpha$-tocopherol separately were added to $1 \mathrm{~mL}$ of 100 $\mu \mathrm{M}$ methanol solution of DPPH. The reaction mixture was incubated in the dark at room temperature for 20 method recommended by the European respectively. The mass spectrometer worked in EI

\section{Materials and methods}

\subsection{Plant material}

To begin with, we selected samples of J. phoenicea, $J$. thurifera and $J$. oxycedrus from the wilderness of Ait Bouguemez valley (Province of Azilal, Morocco). This region is chosen because of the presence of the 3 species at the same ecological conditions. Table 1 shows the ecological traits of the samples' collection setting. Authentication and identification of the plants was done at Laboratory of Ecology and Environment Laboratory, Faculty of Sciences Ben M'Sik (University Hassan II of Casablanca, Morocco). After that, samples were air dried, at room temperature $\left(25^{\circ} \mathrm{C}\right)$ and put them away from sunlight for 21 days until their weight was stable. Finally, they were packed in bags made of paper and kept in a dark, cool and dry place after which their analysis started. minutes. The optical density was monitored at $517 \mathrm{~nm}$ against blank containing methanol. The decrease in optical density of DPPH on addition of test samples in relation to the control was used to calculate the antioxidant activity as percentage of inhibition (\% IP) of DPPH radical:

$\% \mathrm{IP}=\left\{\left(\mathbf{A b S}_{\text {control }}-\mathbf{A b S}_{\text {sample }}\right) /\left(\mathbf{A b S}_{\text {control }}\right)\right\} \times \mathbf{1 0 0}$

$\mathrm{Abs}_{\text {control }}$ is the absorbance of DPPH radical + methanol:

$\mathrm{Abs}_{\text {sample }}$ is the absorbance of DPPH radical + sample or standard.

The antioxidant activity of samples was expressed as IC50 in $\mu \mathrm{g} / \mathrm{mL}$ required inhibiting the formation of DPPH radicals by $50 \%$. A low IC50 value represents a high antioxidant activity. Experiments were carried out in triplicate.

\subsection{Antibacterial activity}

\subsubsection{Bacterial strains}

To evaluate the antibacterial properties of the samples, three strains of pathogenic bacteria were used in the study: Staphylococcus aureus (ATCC 25923), Escherichia coli (ATCC 25922) and Pseudomonas aeruginosa (ATCC 27853).

\subsection{Disc diffusion method}

The antibacterial activities of the EOs were determined by using paper disk diffusion method to screen the efficacy of Eos ${ }^{23}$. The EOs were diluted with dimethylsulfoxyde (DMSO 10\%) at the concentration $100 \mu \mathrm{g} / \mathrm{disc}$. A volume of $10 \mu \mathrm{L}$ of the concentration was impregnated into the paper disk with $6 \mathrm{~mm}$ diameter, and then placed onto Mueller- 
Hinton agar plates $(90 \mathrm{~mm})$, which were previously inoculated on the surface agar with $100 \mu \mathrm{L}$ of $1.5 \times 10^{8} \mathrm{CFU} / \mathrm{mL}$ (equivalent to $0.5 \mathrm{McF}$ arland) suspension for each tested bacterium. Respectively we used disc impregnated with DMSO $10 \%$ and standard disc of Ampicillin as negative and positive controls. In order to trigger excess prediffusion we kept the plates at room temperature for 30 minutes before incubation at $37^{\circ} \mathrm{C}$ for $24 \mathrm{~h}$. We measured diameters of inhibition zones in $\mathrm{mm}$. The experiments were carried out in triplicate.

\subsection{Statistical analysis}

Table 2. Chemical composition of the essential oils of the three species of Juniperus.

\begin{tabular}{|c|c|c|c|c|}
\hline KI & Compound & J.phoenicea & J.thurifera & J. oxycedrus \\
\hline 926 & Tricyclene & 1.33 & - & 0.22 \\
\hline 930 & $\alpha$-Thujene & - & 1.43 & - \\
\hline 939 & $\alpha$-Pinene & 27.92 & 20.07 & 67.33 \\
\hline 953 & $\alpha$-Fenchene & - & 0.21 & $\operatorname{tr}$ \\
\hline 953 & Camphene & 0.53 & 0.2 & 0.43 \\
\hline 957 & Thuja-2.4(10)-diene & - & - & 0.21 \\
\hline 975 & Verbenene & - & - & 0.48 \\
\hline 976 & Sabinene & 0.24 & 19.57 & 1.02 \\
\hline 980 & $\beta$-Pinene & 10.78 & 0.57 & 2.33 \\
\hline 991 & Myrcene & 0.83 & 1.51 & 0.43 \\
\hline 1001 & $\delta$-2-Carene & 1.23 & - & - \\
\hline 1005 & $\alpha$-Phellandrene & 3.74 & $\operatorname{tr}$ & - \\
\hline 1011 & $\delta$-3-Carene & 0.56 & 3.49 & 7.21 \\
\hline 1018 & $\alpha$-Terpinene & 5.09 & 0.48 & $\operatorname{tr}$ \\
\hline 1026 & p-Cymene & 1.19 & 2.6 & 0.74 \\
\hline 1031 & Limonene & - & 2.65 & 0.66 \\
\hline 1031 & $\beta$-Phellandrene & 17.67 & - & - \\
\hline 1040 & (Z)- $\beta$-Ocimene & - & $\operatorname{tr}$ & - \\
\hline 1050 & (E)- $\beta$-Ocimene & - & 0.37 & - \\
\hline 1062 & $\gamma$-Terpinene & 1.01 & 0.94 & 0.26 \\
\hline 1068 & Cis-sabinene hydrate & $\operatorname{tr}$ & $\operatorname{tr}$ & - \\
\hline 1088 & Terpinolene & 2.19 & 0.84 & 0.21 \\
\hline 1098 & Linalool & 0.2 & 2.85 & 0.76 \\
\hline 1102 & $\alpha$-Thujone & - & 0.33 & - \\
\hline 1103 & Cis-4-thujanol & - & 0.29 & - \\
\hline 1104 & Trans-4-thujanol & - & 0.21 & - \\
\hline 1094 & $\alpha$-Pinene oxide & 0.31 & - & - \\
\hline 1119 & Fenchol & - & - & 0.71 \\
\hline 1125 & $\alpha$-Campholenal & - & - & 0.56 \\
\hline 1177 & Terpinen-4-ol & 0.33 & 7.77 & 2.24 \\
\hline 1183 & p-Cymen-8-ol & - & 0.31 & 0.22 \\
\hline 1189 & $\alpha$-Terpineol & 0.45 & 1.12 & 0.39 \\
\hline
\end{tabular}

In each test, the experimental data represent the mean \pm Standard Deviation (SD). The IC50 was obtained with a computer program GraphPad (Prism 8.0.1). Statistical analyses were performed with XLSTAT V.7.1. The significance of the difference among groups was analyzed using ANOVA followed by the Fisher (LSD test) and Dunnett tests. Differences were considered significant at the level $\mathrm{p}<0.05$.

\section{Results and Discussion}

\subsection{Essential Oils composition}

The EOs' chemical composition of the three species of Juniperus is presented in Table 2. 


\begin{tabular}{|c|c|c|c|c|}
\hline 1204 & Verbenone & 1.59 & 0.25 & 0.95 \\
\hline 1217 & Trans-carveol & $\operatorname{tr}$ & - & 1.1 \\
\hline 1228 & Citronellol & 0.22 & - & - \\
\hline 1257 & Linalyl acetate & 0.4 & 3.29 & 0.12 \\
\hline 1272 & Thujyl neo-3-acetate & - & - & 0.3 \\
\hline 1282 & Verbenyl cis-acetate & - & - & 0.72 \\
\hline 1312 & (2E.4E)-2.4-Decadienal & 6.87 & 0.38 & - \\
\hline 1339 & $\delta$-Elemene & - & 0.7 & - \\
\hline 1350 & $\alpha$-Terpinyl acetate & - & 0.25 & - \\
\hline 1376 & $\alpha$-Copaene & - & 0.97 & - \\
\hline 1383 & $\beta$-Bourbonene & 0.76 & - & - \\
\hline 1391 & $\beta$-Elemene & 0.28 & 0.84 & 0.99 \\
\hline 1418 & $\beta$-Caryophyllene & 0.33 & 0.29 & 1.01 \\
\hline 1429 & $\gamma$-Elemene & - & 0.46 & - \\
\hline 1454 & $\alpha$-Humulene & 0.27 & 0.51 & - \\
\hline 1460 & Cis muurola-4(14).5-diene & - & 0.96 & - \\
\hline 1472 & $\gamma$-Gurjunene & - & 0.38 & - \\
\hline 1477 & $\gamma$-Muurolene & - & 0.18 & 0.98 \\
\hline 1480 & Germacrene D & 0.22 & 1.01 & 0.42 \\
\hline 1491 & Valencen & - & 1.99 & - \\
\hline 1499 & $\alpha$-Muurolene & 0.26 & 1.17 & 0.21 \\
\hline 1516 & $\beta$-Curcumene & - & 2.79 & - \\
\hline 1513 & $\gamma$-Cadinene & 1.47 & 0.4 & 0.41 \\
\hline 1524 & $\delta$-Cadinene & 0.32 & 2.09 & 0.56 \\
\hline 1529 & Trans-calamenene & - & 0.43 & - \\
\hline 1538 & $\alpha$-Cadinene & - & 0.5 & 0.35 \\
\hline 1549 & Elemol & 0.47 & 0.42 & $\operatorname{tr}$ \\
\hline 1556 & Germacrene B & - & 0.75 & - \\
\hline 1574 & Germacrene D-4-ol & - & 0.36 & - \\
\hline 1581 & Caryophyllene oxide & - & 0.47 & $\operatorname{tr}$ \\
\hline 1596 & Cedrol & - & 1.61 & - \\
\hline 1630 & $\gamma$-Eudesmol & 0.22 & 0.25 & - \\
\hline 1645 & $\alpha$-Muurolol & - & - & $\operatorname{tr}$ \\
\hline 1649 & $\beta$-Eudesmol & 1.32 & - & - \\
\hline 1652 & $\alpha$-Eudesmol & 1.02 & - & - \\
\hline 1653 & $\alpha$-Cadinol & 0.36 & 0.69 & 0.24 \\
\hline 1666 & Bulnesol & - & 1.63 & - \\
\hline 1686 & Epi- $\alpha$-bisabolol & - & 0.8 & - \\
\hline \multicolumn{2}{|c|}{ Total identified (\%) } & 91.58 & 94.63 & 94.91 \\
\hline \multicolumn{2}{|r|}{ yield $(\%)$} & 1.2 & 0.93 & 0.1 \\
\hline \multicolumn{2}{|c|}{ Monoterpenes hydrocarbon (\%) } & 74.31 & 54.93 & 81.60 \\
\hline \multicolumn{2}{|c|}{ oxygenated monoterpenes $(\%)$} & 9.97 & 17.05 & 8.07 \\
\hline \multicolumn{2}{|c|}{ Sesquiterpenes hydrocarbon (\%) } & 3.91 & 16.42 & 4.93 \\
\hline \multicolumn{2}{|c|}{ Oxygenated sesquiterpenes( $\%)$} & 3.39 & 6.23 & 0.31 \\
\hline
\end{tabular}

-: not detected; tr: traces $(<0.1 \%)$; KI: Kovat's Index ${ }^{1}$ 
$J$. phoenicea provided the highest yield of EOs with approximately $1.2 \%$ compared to $J$. thurifera and $J$. oxycedrus. In contrast, the yield provided by $J$. phoenicea, remains higher than those in Greece $(0.21 \%)$, Spain $(0.30 \%)$, Portugal $(0.41 \%){ }^{24}$, Egypt $(0.36 \%)^{25}$ and Algeria $(0.70 \% \text { to } 0.92 \%)^{26}$. The yield of EO of $J$. thurifera is $0.93 \%$. This yield was different from those reported in the literature. Zeraib et al. ${ }^{27}$ reports values from 0.40 to $0.53 \%$ in different populations of Algerian J. thurifera. The rate provided by $J$. thurifera is still higher than that obtained by El Hajjouji et al. ${ }^{28}$ in Tizi N'tichka (High Atlas Mountains of Morocco) for this species, which did not exceed $0.67 \%$. Finally, J. oxycedrus has the lowest yield among the three species $(0.1 \%)$. This result is lower than that found for the same species in Kosovo $(0.4 \text { to } 1.8 \%)^{29}$, Spain $(0.2 \%){ }^{14}$ and Tunisia $(0.15-0.21 \%)^{30}$. EOs yield showed variations from site to another and these variations could be accounted for by pedoclimatic variations of the growing site or by differences in the genetic arsenal of plants ${ }^{1,27}$.

The analysis of EO of $J$. phoenicea led to the identification of 37 components that represented $91.58 \%$ of the oil. The chemical composition is dominated by the presence of monoterpenes hydrocarbon $(74.31 \%)$ followed by the oxygenated monoterpenes $(9.97 \%)$, sesquiterpenes hydrocarbon $(3.91 \%)$. Oxygenated sesquiterpenes were present in lower quantities with a percentage of $3.39 \%$. Major products were $\alpha$-pinene $(27.92 \%), \beta$-phellandrene $(17.67 \%)$ and $\beta$-pinene $(10.78 \%)$. The chemical composition of this species contains other components of a lower rate. The comparison of the chemical components of the EO of our sample with those of other $J$. phoenicea Oils showed that $\alpha$-pinene is the major product of the Oil. In Tunisia, Ennajar ${ }^{31}$ reported that monoterpenes $(75.9 \%)$ represented the main fraction of the EO, $\alpha$-pinene $(55.7 \%)$ and $\delta$-3carene $(10.7 \%)$ were the major components. The rate of $\alpha$-pinene in the population of Spain is $53.5 \%$ and in Greece, $\alpha$-pinene represent $41.8 \%$ of the Oil ${ }^{24}$. In Algeria, $\alpha$-pinene is the major product of the EO of $J$. phoenicea with an average of $48.08 \%{ }^{26}$. For the Moroccan J. phoenicea, samples collected in the eastern middle Atlas were dominated by $\alpha$-pinene, with a percentage of $64.19 \%{ }^{32}$ and in Oukaimden his rate was $38.2 \%{ }^{15}$.

For J. thurifera 54 components were identified representing $94.63 \%$ of the oil. The monoterpenes hydrocarbon represented the main portion $(54.93 \%)$ followed by the oxygenated monoterpenes $(17.05 \%)$ and sesquiterpenes hydrocarbon $(16.42 \%)$, at last comes oxygenated sesquiterpenes $(6.23 \%)$. The major components were: $\alpha$ - pinene $(20.07 \%)$, sabinene $(19.57 \%)$ and terpinene-4-ol $(7.77 \%)$. A comparison of the chemical composition of EOs of J. thurifera from Algeria showed some quantitative differences. Monoterpenes hydrocarbon varied from $18.6 \%$ to $40.1 \%$ in different populations of Algerian J. thurifera and the major constituent was sabinene $(5.2-20 \%)^{27}$. In Morocco, Achak ${ }^{15}$ reported that the major constituents of EO of Oukaimden (Western high Atlas, Morocco) were sabinene (16.5\%) and $\gamma$-terpinene $(9.3 \%)$. Another study showed that the EO of $J$. thurifera collected in eastern middle Atlas Mountains of Morocco are rich in monoterpenes $(97.09 \%)$ and the major constituent was $\beta$-pinene $(36.26 \%)^{33}$.

The study of the EO of $J$. oxycedrus showed the presence of 38 components accounting for approximately $94.91 \%$. Monoterpenic hydrocarbon fraction was found predominant in EO composition $(81.60 \%)$. However, the contents of oxygenated monoterpenes, sesquiterpenes hydrocarbon and oxygenated sesquiterpenes were $8.07 \%, 4.93 \%$ and $0.31 \%$, respectively. $\alpha$-pinene $(67.33 \%)$ and $\delta$-3-carene $(7.21 \%)$ were the major components. In Spain, Llorens-Molina ${ }^{14}$ reported that monoterpenic hydrocarbon fraction was also found predominant in EO composition of leaves both for siliceous and calcicolous locations (72.5-71.4\%). $\alpha$-pinene was also the main component accounting for $42 \%$ to $53.2 \%{ }^{14}$. Another study of $J$. oxycedrus in Lebanon showed that EO also contains as majority components $\alpha$-pinene with a rate of $27.4 \%$, in addition to myrcene (18.9\%), $\alpha$-phellandrene $(7.1 \%)$ and limonene $(6.7 \%)$ ${ }^{34}$. Monoterpenes, with a percentage ranging between $34.94 \%$ and $81.25 \%$, were the main class of constituents in Italy ${ }^{35}$. The EOs from leaves collected in Tunisia showed sesquiterpenes as main class of constituents, ranging from $34.78 \%$ to $44.16 \% 35$. Identification of the volatile constituents of the EO of J. oxycedrus from the north centre region of Morocco showed high contents of $\alpha$-pinene $(31.25 \%)^{36}$.

The results obtained for the three species are in agreement with those announced by Adams ${ }^{1}$ and Angioni ${ }^{37}$ from the analysis of Juniperus genus, in which pinenes are generally dominant. Because of the genetic diversity ${ }^{38}$, different climatic conditions or of a large geographical diversity ${ }^{1}$ the oils compositions of the same plant showed variability in different populations.

\subsection{Antioxidant activity}

The antioxidant activity of EOs of our samples is showed in Figure 1. The IC50 (half maximal Inhibitory Concentration) values of EOs and those of standards: BHT, vitamin $\mathrm{C}$ and $\alpha$-tocopherol are represented in Table 3. 


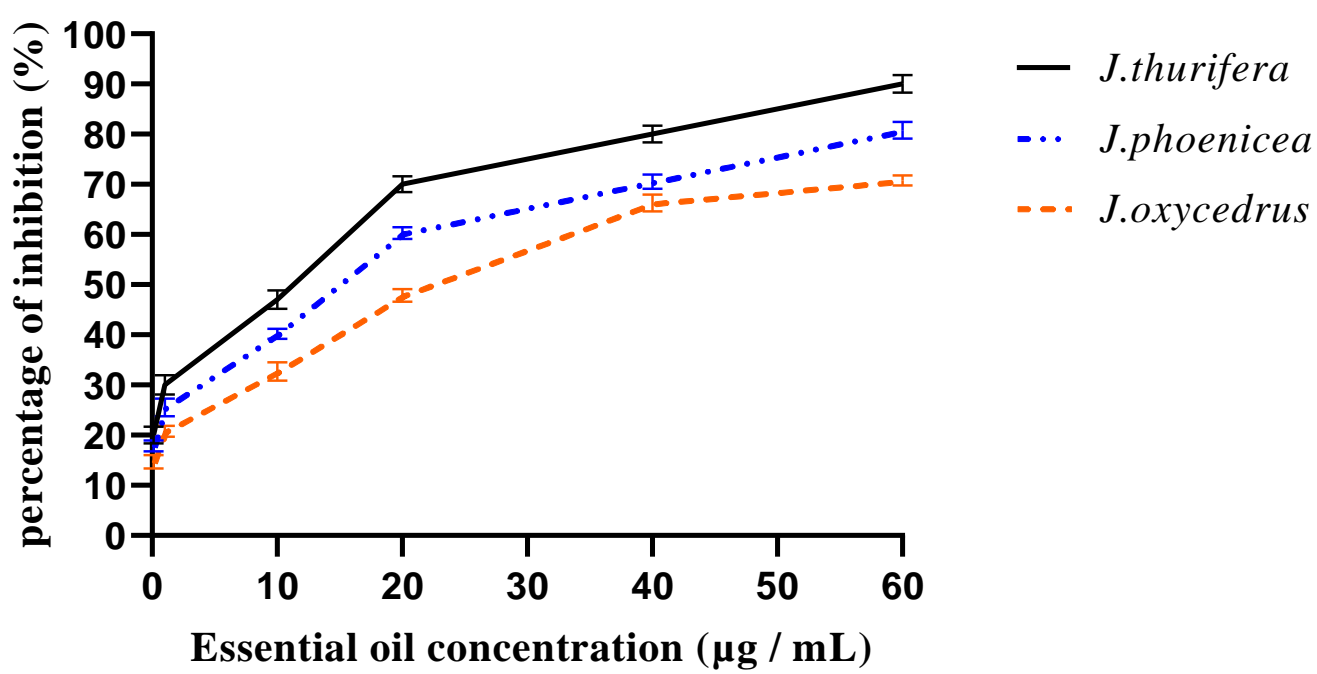

Figure 1. DPPH scavenging activity of EO of J. phoenicea, J. thurifera and J. oxycedrus.

Table 3. IC50 values of the three essential oils and the three standards.

\begin{tabular}{|c|c|}
\hline Samples & $\mathrm{IC} 50(\mu \mathrm{g} / \mathrm{mL})$ \\
\hline J.phoenicea & $14.39 \pm 0.94^{\mathrm{b}}$ \\
\hline J.thurifera & $12.07 \pm 0.74^{\mathrm{a}}$ \\
\hline J.oxycedrus & $22.14 \pm 1.16^{\mathrm{d}}$ \\
\hline BHT & $18.04 \pm 0.49^{\mathrm{c}}$ \\
\hline Vitamin C & $13.45 \pm 0.56^{\mathrm{b}}$ \\
\hline $\boldsymbol{\alpha}$-tocopherol & $18.82 \pm 0.87^{\mathrm{c}}$ \\
\hline Letters superscript denote statistical differences between samples
\end{tabular}

EO of $J$. thurifera has the strongest antioxidant activity against DPPH radical with an IC50 value of $12.07 \mu \mathrm{g} / \mathrm{mL}$, followed by EO of J. phoenicea with an IC50 of $14.39 \mu \mathrm{g} / \mathrm{mL}$. At last comes EO of $J$. oxycedrus $(22.14 \mu \mathrm{g} / \mathrm{mL})$. The antioxidant activity of $J$. thurifera is significantly stronger than the three standards antioxidants: BHT, vitamin $\mathrm{C}$ and $\alpha$-tocopherol. J. phoenicea has activity similar to vitamin $\mathrm{C}$ and higher than BHT and $\alpha$-tocopherol. The antioxidant activity of $J$. oxycedrus is the lowest in comparison with both EOs and standards.

López ${ }^{39}$ identified an important antioxidant effect in several species of the Juniperus genus originating from Spain. Setrani ${ }^{32}$ noted that EO of J. thurifera collected in eastern middle Atlas (Morocco) have the strongest antioxidant activity in comparison with those of J. phoenicea and J. oxycedrus. This result can be explained by the chemical composition of each EO.
Our results are in agreement with studies of Amorati ${ }^{40}$ which showed that the antioxidant properties are in close relationship to the presence of oxygenated compounds (oxygenated monoterpenes and oxygenated sesquiterpenes) (23.28\% for $J$. thurifera and $8.38 \%$ for J. oxycedrus). According to Amorati ${ }^{40}$, oxygenated monoterpenes have been found to have good antioxidant activity because they undergo antioxidation, characterized by very fast termination process thereby reducing overall rate of oxidation. However, it is difficult to assign this activity to the only oxygenated compounds because of the chemical complexity of EOs which can generate a synergy effect between the various compounds ${ }^{41}$.

\subsection{Antibacterial activity}

Results of antibacterial activity of EOs of our samples are shown in Table 4.

Table 4. Diameters of inhibition zones of the three species of Juniperus.

\begin{tabular}{|c|c|c|c|}
\hline & J. phoenicea & J. thurifera & J. oxycedrus \\
\hline S. aureus & $30.55 \pm 2.65^{\mathrm{a}}$ & $31.12 \pm 3.11^{\mathrm{a}}$ & $22.89 \pm 2.48^{\mathrm{ab}}$ \\
\hline E. coli & $11.32 \pm 2.98^{\mathrm{c}}$ & $13.23 \pm 2.59^{\mathrm{c}}$ & $11.20 \pm 2.10^{\mathrm{c}}$ \\
\hline $\boldsymbol{P}$. aeruginosa & $17.20 \pm 3.54^{\mathrm{b}}$ & $18.27 \pm 2.29^{\mathrm{b}}$ & $20.22 \pm 3.30^{\mathrm{b}}$ \\
\hline
\end{tabular}

Letters superscript denote statistical differences between samples

Ours results showed that $S$. aureus was very sensitive to the EOs of the three species with diameters of inhibition zones of $31.12 \mathrm{~mm}, 30.55 \mathrm{~mm}$ and $22.89 \mathrm{~mm}$ respectively of $J$. thurifera, J. phoenicea 
and $J$. oxycedrus. P. aeruginosa and E. coli were more resistant. Our results are in agreement with several works. As shown in studies of the antibacterial activity of EOs of $J$. oxycedrus from Morocco and Tunisia E. coli was highly resistant to this Oil whereas $S$. aureus was the most sensitive strain ${ }^{28,42}$. S. aureus was very sensitive to the EO of Algerian $J$. thurifera and two Pseudomonas strains proved resistant ${ }^{27}$. Bonsignore ${ }^{43}$ confirmed that the EOs of Sardinian $J$. oxycedrus are active on Gram(+) bacteria.

Although, there were many differences in the chemical composition of the three species' EOs, their antibacterial activity was still the same. We also noticed that $\operatorname{Gram}(+)$ bacteria $(S$. aureus) are more sensitive to EOs of the three samples than Gram(-) bacteria (E. coli and $P$. aeruginosa). This is mainly due to the fact that Gram(-) bacteria possess an outer membrane that is more complex, rigid and rich in lipopolysaccharide (LPS), this outer membrane limits the diffusion of hydrophobic compounds. Yet, $\operatorname{Gram}(+)$ bacteria lacks such a membrane and possess instead peptidoglycan wall which is not thick enough to fight small antimicrobial molecules, thus making the cell membrane easily accessible ${ }^{44,45}$. Besides, Gram(+) bacteria can facilitate the penetration of hydrophobic compounds of EOs owing to the lipophilic ends of lipoteichoic acid which exists in cell membrane ${ }^{46}$. Furthermore, some constituents of our EOs such as $\alpha$-pinene, $\alpha$-terpineol, $\beta$-phellandrene, $\delta$-3-carene, $\delta$-2-carene and terpinen-4-ol should also be taken into account when dealing with the antibacterial activity of Juniperus species Eos ${ }^{47,48}$.

\section{Conclusion}

The EOs of $J$. phoenicea, J. thurifera and $J$. oxycedrus, obtained from Ait Bouguemez region (Province of Azilal, Morocco), showed a chemical composition rich in monoterpenes hydrocarbon and oxygenated monoterpenes. They showed an important antioxidant activity and a good antibacterial activity against $S$. aureus, which can justify the multiple uses of the three Juniperus in the traditional medicine of Ait Bouguemez region. Thanks to their antioxidant and antibacterial activities, EOsof $J$. thurifera, $J$. phoenicea and $J$. oxycedrus have to be valorized via several domains. However, numerous investigations should be carried out on their mode of action and their probable toxicological effects in order to optimize their potential uses.

\section{References}

1- R.P. Adams, Junipers of the World: The Genus Juniperus; Victoria, BC, Canada: 2nd Ed. Trafford Publ, 2008.

2- A. Farjon, The taxonomy of multiseed junipers (Juniperus Sect. Sabina) in southwest Asia and east Africa (Taxonomic notes on Cupressaceae I), Edinb J Bot., 1992, 49, 251-283.

3- S. Hammi, M. Al Ifriqui, V. Simonneaux L.Auclair, Évolution des recouvrements forestiers et de l'occupation des sols entre 1964 et 2002 dans la haute vallée des Ait Bouguemez (Haut Atlas Central, Maroc), Sécheresse, 2007, 18(4), 271-277.

4- J. Bellakhdar, La Pharmacopée marocaine traditionnelle. Médecine arabe ancienne et savoirs populaires, Ed by Ibis Press, Paris, 1997.

5- A. El Alami, L. Farouk, A. Chait, Etude ethnobotanique sur les plantes médicinales spontanées poussant dans le versant nord de l'Atlas d'Azilal (Maroc), Algerian J Nat Products, 2016, 4 (2), 271-282.

6- A. El Alami, A. Chait, Enquête ethnopharmacologique et ethnobotanique sur les plantes médicinales dans le Haut Atlas central du Maroc, Algerian J. Nat. Products, 2017, 5, 427-445.

7- F. El Azzouzi, L. Zidane, La flore médicinale traditionnelle de la région de Béni Mellal (Maroc). J appl biosci., 2015, 91, 8493-8502.

8- B.E. Van Wyk and M. Wink, Phytomedicines, Herbal drugs and Poisons. Briza, Kew Publishing, Cambridge University Press, Cambridge, UK, 2015.

9- M. Wiesenauer, PhytoPraxis. 5th ed. Springer, Heidelberg, Germany, 2012.

10-D.P. Pavarini, S.P. Pavarini, M. Niehues, N.P. Lopes, Exogenous influences on plant secondary metabolite levels, Anim Feed Sci Technol., 2012, 176, 5-16.

11-A. Szakiel, C. Pączkowski, M. Henry, Influence of environmental abiotic factors on the content of saponins in plants, Phytochem Rev., 2010, 10, 471-491.

12-F. Amezouar, W. Badri, M. Hsaine, N. Bourhim, H. Fougrach, Chemical Composition, Antioxidant and Antibacterial Activities of Leaves Essential Oil and Ethanolic Extract of Moroccan Warionia saharae Benth. \& Coss, J Appl Pharm Sci., 2012, 02 (05), 212-217.

13-H. Rabib, S. Zougagh, M. Hssain, W. Badri, T. Koussa, GC/MS Analysis and Antibacterial Activity of the Essential Oil of Moroccan Tetraclinis articulata (Vahl) Masters, Mediterr.J. Chem., 2019, 8(4), 302-307.

14-A.J.A. Llorens-Molina, S. Vacas, J. Sabater, Essential oil composition of berries and leaves of Juniperus oxycedrus ssp oxycedrus L. from two typical substrates of Valencia (Spain), Nat Volatiles \& Essent Oils., 2016, 3(1), 23-30.

15-N. Achak, A. Romane, A. Abbad, M Ennajar, M. Romdhane, A. Abderrabba, Essential oil composition of Juniperus phoenicea from Morocco and Tunisia, J Essent Oil Bear Plants., 2008, 11, 137-142.

16-S. Rezzi, C. Cavaleiro, A, Bighelli, L. Salgueiro,A.P. Da Cunha, J. Casanova, Intraspecific chemical variability of the leaf essential oil of Juniperus Phoenicea subsp. turbinata from Corsica, Biochem Syst Ecol., 2001, 1, 29 (2), 179-188. 
17-A.F. Barrero, J.F. Quilez del Moral, M.M. Herrador, M. Akssira, A, Bennamara, S. Akkad, M. Aitigri,. Oxygenated diterpenes and other constituents from Moroccan Juniperus phoenicea and Juniperus thurifera var. Africana, Phytochemistry, 2004, 65, 2507-2515.

18-R.P. Adams, The leaf essential oils and chemotaxonomy of Juniperus sect. Juniperus, Biochem Syst Ecol., 1998, 26, 637-645.

19-E. Majewska, M. kozłowska, D. kowalska, E. gruczyńska, Characterization of the essential oil from cone-berries of Juniperus communis L. (Cupressaceae), Herba Pol., 2017, 63(3), 4855.

20-T.A. Misharina, M.B. Terenina, N.I. Krikunowa, Antioxidant properties of essential oils, Appl Biochem and Microbiol, 2009, 45, 642-647.

21-European Pharmacopoeia, Part 1, Maisonneuve SA, Sainte Ruffine, 1983, p. V.4.5.8.

22-W. Pothitirat, M.T. Chomnawang, R. Supabphol, W. Gritsanapan, Composition of bioactive compounds content, free radical scavenging and anti-acne inducing bacteria activities of extracts from the Mangosteen fuit rind at two stages of maturity, Fitoterapia, 2009, 80, 442-447

23-C.H. Collins, P.M. Lynes, J.M. Grange, Microbiological Methods ( $7^{\text {th }}$ Ed), ButterwortHeinemann Ltd., Britain, 1995, pp 175-190.

24-R.P. Adams, A.F. Barrero,A. Lara, Comparisons of the leaf essential oils of Juniperus phoenicea, J. phoenicea subsp eu-mediterranea Lebr. \& Thiv. and J. phoenicea var. turbinata (Guss), Parl J Essent Oil Res., 1996, 8, 367-371.

25-S.A. El-Sawi, H.M. Motawae, A.M. Ali, Chemical composition, cytotoxic activity and antimicrobial activity of essential oils of leaves and berries of Juniperus phoenicea L. grown in Egypt, Afr J Tradit Complementary Altern Me., 2007, 4(4), 417-426.

26-M. Ramdani, T. Lograda, H. Silini, A. Zeraib, P. Chalard, G. Figueredo, M. Bouchaala, S. Zerrar, Antibacterial Activity of Essential oils of Juniperus Phoenicea from Eastern Algeria, J App Pharm Sci, 2013, 3 (11), 022-028.

27-A. Zeraib, M. Ramdani, L. Boudjedjou, P. Chalard, G. Figuredo, Characterization and chemosystematics of Algerian thuriferous juniper (Juniperus thurifera L.), J Appl Bot Food Qual, 2014, 87, 249-255.

28-H. El Hajjouji, C. Elagdi, R. Rahhal, S.Gmouh, M. Hsaine, H. Fougrach1, W. Badri, Chemical composition and antibacterial activity of essential oils extracted from three species of Moroccan Juniperus, Res J Pharm Biol Chem Sci., 2019, 10(3), 515-522.

29-A. Hajdari, B. Mustafa, V. Gashi, D. Nebija, A. Ibraliu, J. Novak, Chemical composition of the essential oils of ripe berries of Juniperus oxycedrus L., growing wild in Kosovo, Biochem Syst Ecol, 2014, 57, 90-94.

30-H. Medini, A. Elaissi, M. Khouja, I. Chraief,
F. Farhat, M. Hammami, F. Harzallah-Skhiri, Leaf essential oil of Juniperus oxycedrus L.(Cupressaceae) harvested in Northern Tunisia: composition and intra-specific variability, Chem Biodivers, 2010, 7(5), 1254.

31-M. Ennajar, J. Bouajila,A. Lebrihi, The influence of organ, season and drying method on chemical composition and antioxidant and antimicrobial activities of Juniperus phoenicea L. essential oils, J Sci Food Agric., 2010, 90(3), 462-470

32-B. Satrani, M. Ghanmi, N. Mansouri, N. Amusant, Antioxidant properties of essential oils extracted from three species of Moroccan junipers, Environ Sci Ind J., 2015, 11 (7), 239-247.

33-N. Mansouri, B. Satrani, M. Ghanmi, L. El Ghadraoui, A. Aafi, A. Farah, Valorisation des huiles essentielles de Juniperus thurifera et de Juniperus oxycedrus du Maroc, Phytothérapie, 2010, 8, 166-170.

34-M.R. Loizzo, R. Tundis, F. Conforti, A.M. Saab,G.A. Statti, F. Menichini, (2007). Comparative chemical composition, antioxidant and hypoglycaemic activities of Juniperus oxycedrus ssp. oxycedrus L. berry and wood oils from Lebanon, Food Chem., 2007, 105(2), 572-578.

35-F. Roma-Marzio, B. Najar, J. Alessandri, L. Pistelli, L. Peruzzi, Taxonomy of prickly juniper (Juniperus oxycedrus group): A phytochemical-morphometric combined approach at the contact zone of two cryptospecies, Phytochemistry, 2017, 141, 48-60.

36-E. Derwich, R. Chabir, Identification of the volatile constituents of the essential oil of Juniperus oxycedrus (Cupressaceae) from the north centre region of Morocco, Asian J Pharm Clin Res, 2011, 4(1), 50-54.37-

37. A. Angioni, A. Barra, M.T. Russo, V. Coroneo, S. Dessí, P, Cabras, Chemical composition of the essential oils of Juniperus from ripe and unripe berries and leaves and their antimicrobial activity, J Agric Food Chem, 2003, 51(10), 3073-3078.

38-M. Skoula, J.E. Abbes, C.B. Johnson, Genetic variation of volatiles and rosmarinic acid in populations of Salvia fruticosa Mill. growing in Crete. Bichem Systemt Ecol, 2000, 28, 551-561.

39-V. López, S. Akerreta, E. Casanova, J. García-Mina, R. Cavero, M, Calvo (2008) Screening of Spanish Medicinal Plants for Antioxidant and Antifungal Activities, Pharm Biol, 2008, 46(9), 602-609.

40-R. Amorati, M.C. Foti, L. Valgimigli, Antioxidant Activity of Essential Oils, J. Agric Food Chem., 2013, 61 (46), 10835-10847.

41-S. Chouhan, K. Sharma, S. Guleria, Antimicrobial Activity of Some Essential OilsPresent Status and Future Perspectives, Medicines, 2017, 4, 58. 
42-H. Medini, A. Elaissi, M. Khouja, I. Chraief, F. Farhat, M. Hammami, F. Harzallah-Skhiri, Leaf essential oil of Juniperus oxycedrus L.(Cupressaceae) harvested in Northern Tunisia: composition and intra-specific variability, Chem Biodivers, 2010, 7(5), 1254.

43-L. Bonsignore, G. Loy, D. Secci, A. De Logu, G. A. Palmieri, Preliminary microbiological screening of Sardinian plants, Fitoterapia, 1990, 61, 339-341.

44-M. Hyldgaard, T. Mygind, R.L. Meyer, Essential oils in food preservation: Mode of action, synergies and interactions with food matrix components, Front Microbiol, 2012, 3, 1-24.

45-K.G. Zinoviadou,K.P. Koutsoumanis,C.G. Biliaderis, Physico-Chemical properties of whey protein isolate films containing oregano oil and their antimicrobial action against spoilage flora of fresh beef, Meat Sci, 2009, 82, 338-345.

46-S.D. Cox, C.M. Mann, J.L. Markham, H.C. Bell, J.E. Gustafson,J.R. Warmington, S.G. Wyllie, The mode of antimicrobial action of the essential oil of Melaleuca alternifolia (tea tree oil), J Appl Microbiol, 2000, 88, 170-175.

47-L.O. Alessandra, B.L. Roberta, A.C. Fernando, N.E. Marcos, Volatile compounds from pitanga fruit (Eugenia uniflora L.), Food Chem, 2005, 99, 1-5.

48-S. Cosentino, C.I.G. Tuberoso, B. Pisano, M. Satta, V. Mascia, E. Arzedi, F. Palmas, In vitro antimicrobial activity and chemical composition of Sardinian Thymus essential oils, Lett. Appl Microbiol, 1999, 29, 130-135. 